\title{
Effectiveness of Povidone lodine and Antibiotic Treatment on Postpartum Reproductive Disorders in Beef Cattle
}

\author{
Erif Maha Nugraha Setyawan ${ }^{1 *}$, Yosua Kristian Adi $^{1}$, Sri Gustari ${ }^{1}$, Asmarani Kusumawati ${ }^{1}$, \\ Agung Budiyanto ${ }^{1}$, Surya Agus Prihatno ${ }^{1}$ \\ ${ }^{1}$ Faculty of Veterinary Medicine, Universitas Gadjah Mada, Jl. Fauna No.2, Karangmalang, \\ Yogyakarta 55281, Indonesia
}

\begin{abstract}
This research was conducted to find out the reproductive disorders of postpartum and the effectiveness of its treatment in various nations of beef cattle. A total of 30 beef cattle raised in cattle groups in the D.I.Y. area was used as research samples. Cows are divided into three groups namely control group, iodine povidone infusion group, and antibiotic infusion group. First, second, and third months postpartum are performed clinical examination, blood collection, and rectovaginal examination. Haematological and clinical conditions in postpartum beef cattle have variations but most show a high profile of leukocytes in $1^{\text {st }}$ to $5^{\text {th }}$ week. Povidone iodine infusion treatment in $1^{\text {st }}$ week postpartum can reduce bacterial infection until $5^{\text {th }}$ week and can accelerate the uterine involution process during the recovery period.
\end{abstract}

\section{Introduction}

The condition of infertile postpartum is associated with inactive ovaries, so follicle growth does not allow the follicles to mature enough to be ovulated [1]. The incidence of postpartum anestrus varies among herds of cows, the incidence ranges from 10-40\% [2]. Gebrekidan et al. [3] stated that as a result of parturition, It decreased ovarian function, which caused low ovum quality, uterine and oviduct disorders (15.30\%), which caused fertilization and implantation disorders $(15.30 \%)$, which vaginal disorder caused disruption of the breeding process $(6.4 \%)$. The period after childbirth is declared successful if it is characterized by the complete process of uterine involution and the return of ovarian function. According to Wathes et al. [4] and Saut et al. [5] that after parturition, the uterus undergoes remodeling i.e. the reduction in uterine size, repair of damaged cells, and the return of tissue build to normal conditions after placental discharge. According to Wathes et al. [4] that the uterus returns to normal condition within 2-3 weeks after delivery if there is no bacterial contamination. The success of uterine involution is characterized by the re-production of estrogen, reduced and reduced size of the uterus, and supported by the release of the uterus from bacterial contamination during childbirth or contamination from placental retention events [6]. Inflammation of the endometrial lining of the uterus, usually occurs because of pathogenic

* Corresponding author: erif_maha@ugm.ac.id 
bacterial infections mainly occurring through the vagina and through the cervix thus contaminating the uterus during the parturition [7,8]. The infection of microorganisms resulted in endometrial inflammation resulting in endometritis. The severity of endometritis depends on the ferocity of the bacteria infecting, the number of bacteria and the endurance of the patient's animal. Endometritis is classified into two groups: clinical endometritis and subclinical endometritis [9]. Clinical endometritis is described in the presence of purulent or mucopurulent discharge that can be found on the outside or in the anterior vagina or with a cervical diameter of more than $7.5 \mathrm{~cm}$ after the 26th day of postpartum [7,9]. Subclinical endometritis is depicted with cervical size $\leq 7.5 \mathrm{~cm}$ and/or abnormal fluid in the uterine lumen [7] and the presence of polymorphonuclear leukocytes (PMN) in uterine cytology samples and or ultrasound images of existing fluids. Reproductive disorders in cows due to bacterial contamination of the uterine lumen after parturition and the bacteria are pathogenic causing clinical diseases. Sub fertile conditions associated with uterine infections involve hypothalamic, pituitary, and ovarian disorders, and have a direct effect on the uterus and persist until a clinical disease arises. Absorption of bacterial components by the uterus can prevent follicle spikes in the LH phase and ovulation. In addition, the growth of dominant follicle becomes slow so that it has a low estradiol level. Thus, it is important to diagnose and treat post-child reproductive diseases quickly and effectively [8].

Research and studies on diseases of clinical reproductive disorders have been conducted but not conducted comprehensively and measurably regarding the type, etiology and severity accompanied by information on blood picture. By using complete information, it can do management therapy that has long been known, namely infusion of povidone iodine and antibiotics. This research was conducted to find out the reproductive disorders of postpartum and the effectiveness of its treatment in various nations of beef cattle.

\section{Materials and Methods}

\subsection{Materials}

The research will be conducted in several partner livestock groups of the Department of Reproduction and Midwifery. The cows used are cows from various nations encountered and as many as 30 postpartum beef cattle were kept in the partner livestock group of the Department of Reproduction and Obstetrics in the Sleman area were carried out infusion of povidone iodine and antibiotics. A set of ultrasound tools are used as an accurate tool in determining the diagnostic process of reproductive disorders, uterine and ovarian responses.

\subsection{Methods}

\subsubsection{Data Collection}

Selection of samples of beef cattle with postpartum reproductive disorders is conducted based on anamnesis / recording from farmers followed by examination per rectal and ultrasound to record the initial condition of the uterus. Infusion treatment of povidone iodine $1 \%$ was administered as much as $250 \mathrm{ml}$ per head in group 1, intra-uterine antibiotic administration in group 2 and the control group was not treated. All samples were injected with $10 \mathrm{ml}$ multivitamin ADE. Clinical examination, blood retrieval, and uterine observations are conducted at weeks 1,5 and 9 of postpartum. 


\subsubsection{Data Analysis}

The data collected are the breed of the mother cow, the age of the mother, the reproductive status, the size of the uterus and the condition of the ovaries. The data will be analyzed by descriptive analysis method and Analysis of Variance (ANOVA).

\section{Results and Discussions}

\subsection{Clinical Condition}

Based on the results that have been obtained it was known that the average temperature of postpartum heifer $\mathrm{H}+3$ is $38.86^{\circ} \mathrm{C}$ while the average pulsus is $79.1 \mathrm{x} / \mathrm{min}$, and the breath frequency is $32.9 \mathrm{x} / \mathrm{min}$. Based on the aspect of reproduction, the average diameter of cervix postpartum heifer $\mathrm{H}+3$ is $6.56 \mathrm{~cm}$, while the size of the postpartum uterine was similar with the size of 3-4 months pregnant uterine. The blood picture shows an average red blood cell of $5.23 \times 10^{6}$ cells $/ \mu \mathrm{l}$ and white blood cells of 9,426 cells $/ \mu 1$.

A comparison between the results and literature shows that $\mathrm{H}+3$ postpartum inductees of beef cattle kept in the cattle group of the D.I.Y. region have normal body temperature and pulsus, while the frequency of breathing has slightly increased. The picture of red blood cells and white blood cells was still within normal limits. This indicates that the condition of $\mathrm{H}+3$ postpartum of cows in Indonesia in general is still good. No clinical changes nor hematology of erythrocytes and leukocytes.

\subsection{Hematological Condition}

Due to lack of sterile in the reproductive tract, postpartum cows can experience inflammation. Frequent infections are caused by the bacteria A. pyogenes, F. necrophorum, E. coli, Streptococci, Mannheimia haemolytica and Proteus [10]. Sheldon et al. [11] states the herpes-4 cow virus (BoHV-4) accelerates damage to uterine endometrium cells. As a result of infection can cause changes in leukocytes. To support the results of physical examination, the cows in this study were examined leukocytes and its differentials (Table 1). The total leukocyte test results in the control group in weeks 1,5 and 9 respectively were $12,833.33 \pm 8,020.34 ; 9,616.67 \pm 3,454.10 ; 8,483.33 \pm 2,252.96$ cells/ $\mu 1$ treatment group was $9083.33 \pm 301.39 ; 7750.00 \pm 1650.00 ; 9566.67 \pm 2049.59$ cell $/ \mu 1$ (Table 1$)$.

Anderson and Lorraine [12] stated that the increase in the total number of leukocytes is a physiological response in protecting the body from attacks of microorganisms. According to Scott and Elizabeth [13] leukocytes work to protect the body from infection by means of phagocytosis, synthesis of antibody molecules, destruction of bacteria, cleaning of cell remains in inflammatory tissues and protecting infected areas. The results of the total leukocyte examination in this study are still normal and in accordance with those presented by Wood and Quiroz-Rocha [14], namely 5,100 cells/ $\mu$ l up to 13,300 cells/ $\mu$ l.

Differential leukocytes showed that lymphocyte values in the control group in the $1^{\text {st }}, 5^{\text {th }}$ and $9^{\text {th }}$ week respectively were $3539.33 \pm 3056.50 ; 3370.17 \pm 2025.98 ; 3384.00 \pm 1064.63$ cells $/ \mu$ l and treatment group was $2282.17 \pm 682.73 ; 3363.83 \pm 997.34 ; 3811.83 \pm 2428.79$ cells/ $\mu$ l (Table 1). The result corresponds to several references, where normal lymphocyte values are $1.8-8.1 \times 10^{3}$ cells $/ \mu 1$ [14]. Lymphocyte values in this study were declared normal and the immune condition optimal. Lymphocytes serve as a response to antigens by forming antibodies circulating in the blood or in cellular immunity. Lymphocytes by function are divided into B lymphocyte cells (humoral immunity with the production of antibodies and memory cells) and T lymphocyte cells (cellular intermediate immunity) [14]. 


\subsection{Uterine Involution}

The measurement of uterine diameter in this study was only done in weeks 5 and 9 . The measurement of uterine diameter in this study was only done in weeks 5 and 9 . The results of this study showed that from week 5 to week 9 the diameter of uterine horn is getting smaller, from $4.92 \pm 1.56 \mathrm{~cm}$ to $2.92 \pm 0.20 \mathrm{~cm}$, with a difference of $2.00 \mathrm{~cm}$ in control cows and $5.00 \pm 0.00 \mathrm{~cm}$ to $3.17 \pm 0.41 \mathrm{~cm}$, with a difference of $1.83 \mathrm{~cm}$ in treated cows. The results of this study showed that from week 5 to week 9 the diameter of uterine horn is getting smaller, from $4.92 \pm 1.56 \mathrm{~cm}$ to $2.92 \pm 0.20 \mathrm{~cm}$, with a difference of $2.00 \mathrm{~cm}$ in control cows and $5.00 \pm 0.00 \mathrm{~cm}$ to $3.17 \pm 0.41 \mathrm{~cm}$, with a difference of $1.83 \mathrm{~cm}$ in treated cows. uterine horns at week 1 are not measured due to the oversized size of uterine horns and cannot be separated between the two horns. uterine horns at week 1 are not measured due to the oversized size of uterine horns and cannot be separated between the two horns. Morrow et al. (1969) said that the change in the size of the uterine diameter occurs between the $4^{\text {th }}$ day and the $9^{\text {th }}$ day of the postpartum, then the change is faster and significant on the $10^{\text {th }}$ to the $14^{\text {th }}$ day of the postpartum. After that, the change gradually decreases, and the entire uterine organ is usually palpable on the $8^{\text {th }}$ and $10^{\text {th }}$ day of the postpartum. The diameter of the uterus at week 1 is greater than in weeks 5 and 9 can be caused by the filling of the uterus by lochia fluid. Liquid lochia drastically reduced week 2 [8]. The size and shape of a normal uterus is influenced by its species, age, nation and reproductive status [15].

Although there was a slight difference in the difference (delta) reduction in diameter in the control cow group $(2 \mathrm{~cm})$ and the treatment group cow $(1.83 \mathrm{~cm})$, but the change in the size of the uterine horns of all cows in this study was still in the normal category. According to Kasimanickam et al. [7], primipara PO cows have a diameter of uterine postpartum week 1 which is $8.5 \mathrm{~cm}$, in week 5 that is $4.5 \mathrm{~cm}$ and in week 7 which is $4.6 \mathrm{~cm}$. Bovine PO multipara week 1 is $8.5 \mathrm{~cm}$, in week 5 is $5 \mathrm{~cm}$ and week 7 is $4.2 \mathrm{~cm}$.

\section{Conclusion}

In conclusion, postpartum beef cattle in Yogyakarta showed a variety of hematological and clinical conditions, most of which showed an increase in leukocyte profile. Povidone iodine infusion treatment $1 \%$ in week 1 postpartum can reduce bacterial infections up to week 5 and can accelerate the process of uterine involution during recovery period. Hematological and clinical conditions in postpartum beef cattle have variations but most show a high leukocyte profile in weeks 1 to week 5 . Povidone iodine infusion treatment $1 \%$ in week 1 postpartum may be able to reduce bacterial infections up to week 5 and can accelerate the process of uterine involution during recovery.

\section{References}

1. F. Montiel, C. Ahuja, Anim Reprod Sci 85, 1-26 (2005)

2. Yuherman, Reswati, Y.F. Kurnia, Indahwati, Khalil, Pak J Biol Sci 20, 8, 390-396 (2017)

3. M.A. Gohar, M.A. Elmetwally, A. Montaser, S.M. Zaabel, J Vet health care 1, 45-53 (2018)

4. D..C Wathes, Z. Cheng, M.A. Ferwick, R. Fitzpatrick, J. Patton, Reproduction 141, 269281 (2011)

5. J.P.E. Saut, R.S.B.R. Oliviera, C.F.G. Martins, A.R.F. Moura, S.A. Tsuruta, N.R. Nasciutti, R.M. Santos, S.A. Headley, Vet Not 17, 1, 16-25 (2011) 
6. E.S.E. Hafez and B. Hafez, Reproduction in Farm Animal $7^{\text {th }}$ ed. (2000)

7. R. Kasimanickam, J.M. Cornwell, R.L. Nebel, J Anim R Sci 95, 214-223 (2006)

8. I.M. Sheldon, Reproduction Management Bulletin (Intervet) 2, 1, 1-5 (2007)

9. S.J. LeBlanc, T.F. Duffield, K.E. Leslie, K.G. Bateman, G.P. Keefe, J.S. Walton, W.H. Johnson, J Dairy Sci 85, 2223-2236 (2002)

10. E.J. Williams, D.P. Fischer, D.U. Pfeiffer, G.C. England, D.E. Noakes, H. Dobson, I.M. Sheldon, Theriogenology 63, 102-117 (2005)

11. I.M. Sheldon, E.J. Williams, A.N.A. Miller, D.M. Nash, and S. Herath, The Veterinary Journal 176, 115-121 (2008)

12. S.P. Anderson, M.W. Lorraine, Patofisiologi Konsep Klinis Proses-Proses Penyakit $6^{\text {th }}$ ed. (2006)

13. A.S. Scott and F. Elizabeth, Body Structure and Function $11^{\text {th }}$ ed. (2009)

14. D. Wood and G. Quiroz-Rocha. Normal hematology of cattle $6^{\text {th }}$ ed. Ames (2010)

15. Ismaya. Bioteknologi Inseminasi Buatan pada Sapi dan Kerbau (2014) 
Table 1. Comparison of total and differential leukocytes in the control group and treatment of Povidone iodine $1 \%$.

\begin{tabular}{|c|c|c|c|c|c|c|c|}
\hline Week & \multicolumn{2}{|c|}{1} & \multicolumn{2}{|c|}{5} & \multicolumn{2}{|c|}{9} & \multirow{2}{*}{$\begin{array}{c}\text { Normal } \\
\text { Standart }\end{array}$} \\
\hline Group & Control & Treatment & Control & Treatment & Control & Treatment & \\
\hline $\begin{array}{l}\text { Leucocyte } \\
(\text { cells } / \mu \mathrm{l})\end{array}$ & $\begin{array}{c}12833,33 \pm \\
8020,34\end{array}$ & $\begin{array}{c}9083,33 \pm \\
301,39 \\
\end{array}$ & $\begin{array}{c}9616,67 \pm \\
3454,10 \\
\end{array}$ & $\begin{array}{c}7750,00 \pm \\
1650,00 \\
\end{array}$ & $\begin{array}{c}8483,33 \pm \\
2252,96\end{array}$ & $\begin{array}{c}9566,67 \pm \\
2049,59 \\
\end{array}$ & $\begin{array}{l}5100- \\
13300^{*}\end{array}$ \\
\hline $\begin{array}{l}\text { Neutrophil } \\
(\text { cells } / \mu \mathrm{l})\end{array}$ & $\begin{array}{c}7927,17 \pm \\
4706,61\end{array}$ & $\begin{array}{c}4829,50 \pm \\
1089,63 \\
\end{array}$ & $\begin{array}{c}4933,33 \pm \\
1516,45 \\
\end{array}$ & $\begin{array}{c}2632,83 \pm \\
903,86\end{array}$ & $\begin{array}{c}3041,67 \pm \\
833,44\end{array}$ & $\begin{array}{c}3185,67 \pm \\
2118,19 \\
\end{array}$ & $\begin{array}{l}1700- \\
6000^{*}\end{array}$ \\
\hline $\begin{array}{l}\text { Lymphocy } \\
\text { te (cells } \\
/ \mu \mathrm{l})\end{array}$ & $\begin{array}{c}3539,33 \pm \\
3056,50\end{array}$ & $\begin{array}{c}2282,17 \pm \\
682,73\end{array}$ & $\begin{array}{c}3370,17 \pm \\
2025,98\end{array}$ & $\begin{array}{c}3363,83 \pm \\
997,34\end{array}$ & $\begin{array}{c}3384,00 \pm \\
1064,63\end{array}$ & $\begin{array}{c}3811,83 \pm \\
2428,79\end{array}$ & $\begin{array}{l}1800- \\
8100^{*}\end{array}$ \\
\hline $\begin{array}{l}\text { Monocyte } \\
(\text { cells } / \mu \mathrm{l})\end{array}$ & $339,83 \pm 218,82$ & $579,83 \pm 337,25$ & $173,33 \pm 196,63$ & $219,83 \pm 232,39$ & $581,50 \pm 309,61$ & $322,50 \pm 387,60$ & $100-700^{*}$ \\
\hline $\begin{array}{l}\text { Eosinophil } \\
(\text { cells } / \mu \mathrm{l})\end{array}$ & $774,50 \pm 115,30$ & $\begin{array}{c}1394,83 \pm \\
1536,62 \\
\end{array}$ & $\begin{array}{c}1563,50 \pm \\
397,89 \\
\end{array}$ & $\begin{array}{c}1533,50 \pm \\
762,56 \\
\end{array}$ & $\begin{array}{c}1426,00 \pm \\
729,20\end{array}$ & $\begin{array}{c}2246,67 \pm \\
1704,01\end{array}$ & $100-1200^{*}$ \\
\hline
\end{tabular}

*: Wood and Quiroz-Rocha (2010) 